\title{
Association of Paranasal Sinus Osteoma and Intracranial Mucocele -Two Case Reports-
}

\author{
Kamil Melih AKAY, Önder ÖNGÜRÜ*, Sait ŞIRIN, Bülent CELASUN*, \\ Engin GÖNÜL, and Erdener TIMURKAYNAK \\ Departments of Neurosurgery and *Pathology, Gulhane Military Medical Academy, \\ Ankara, Turkey
}

\begin{abstract}
Two young adult males presented with paranasal sinus osteoma associated with mucocele. A 20-yearold man presented with headache and seizure, and another 20-year-old man presented with headache, frontal deformity, and visual disturbances. Both patients underwent surgery and satisfactory results were obtained. Isolated paranasal sinus osteomas are benign and slow-growing tumors, but may become more aggressive in association with mucoceles. The higher aggressiveness of the lesions may be due to the presence of the mucocele. Calcification and ossification of the mucocele probably contributes to the unexpected enlargement of the osteoma.
\end{abstract}

Key words: mucocele, osteoma, paranasal sinus, pathophysiology, surgery

\section{Introduction}

Paranasal sinus osteomas are histologically benign and slow-growing true neoplasms, but sometimes cause secondary mucoceles due to occlusion of the sinus openings. ${ }^{14)}$ Such secondary mucoceles can erode the bone and extend into the cranial cavity, resulting in life-threatening dangerous intracranial complications. The association of paranasal sinus osteoma with secondary mucocele extending intracranially is rare, with less than 20 reported

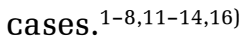

Here we describe two new cases of paranasal sinus osteoma and secondary mucocele extending intracranially and discuss a new hypothesis for the pathogenesis of the association.

\section{Case Reports}

Case 1: A 20-year-old man presented with headache and sudden onset of convulsion. He was transferred to our department. He had no history of prior seizure. Neurological examination found no abnormalities. Cranial radiography demonstrated a right

Received March 4, 2003; Accepted December 12, 2003 frontal calcified mass (Fig. 1C). Computed tomography (CT) revealed a right frontal calcified mass surrounded by a hypodense lesion causing slight midline shift. Magnetic resonance (MR) imaging showed a lesion occupying the right frontal lobe adjacent to the greater wing of the sphenoid bone and right orbital roof with hypointense and hyperintense regions (Fig. 1A, B). The inhomogeneously enhanced lesion contained hyper- and hypointense areas.

The patient underwent right frontal craniotomy for total removal of the intradural and extradural multiloculated cystic lesions. The cystic lesion was suctioned and the bony lesion was removed with an air drill. The dural defect was repaired with pericranium (Fig. 1D). The mucous membranes of the frontal sinus were curetted and the residual frontal sinus was packed with muscle. The final histological diagnosis was mucocele and osteoma (Fig. 2). The postoperative course was uneventful. Twelve months later the patient was doing well without any seizures.

Case 2: A 20-year-old man presented with progressive headaches, visual disturbances, and frontal asymmetry. He was admitted to our department. He was alert and had no focal neurological signs. Radiography and CT depicted a calcified mass 

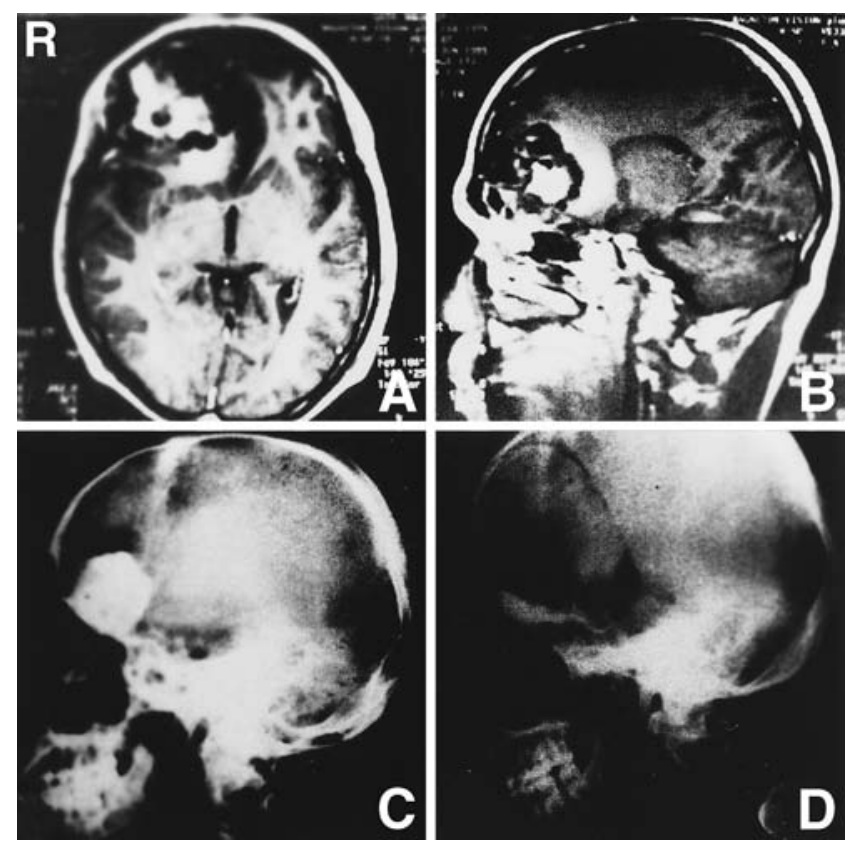

Fig. 1 Case 1. (A) Axial and (B) sagittal $T_{1-}$ weighted magnetic resonance images with contrast medium. Note midline shift due to osteoma and mucocele association. (C) Pre- and (D) postoperative lateral craniograms showing the osteoma and mucocele were removed totally via right frontal craniotomy.

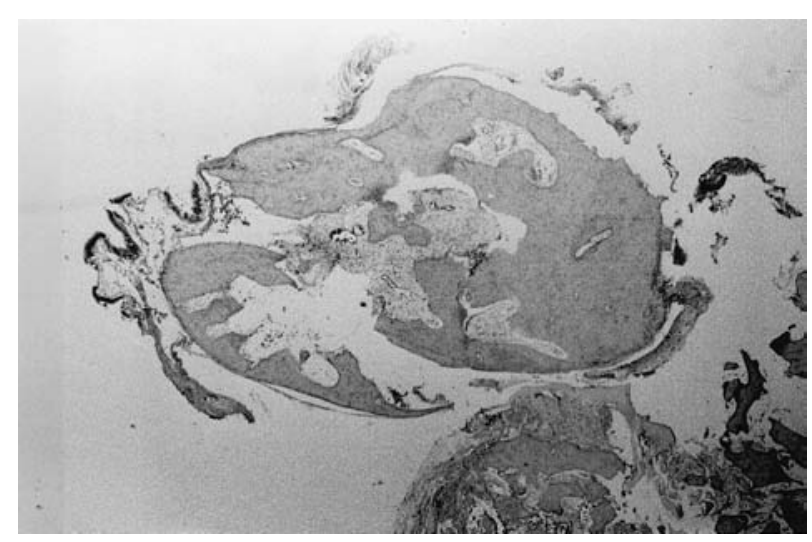

Fig. 2 Case 1. Photomicrograph showing an island of apparently mature bone within the mucocele tissue. HE stain, $\times 50$.

lesion situated on the superomedial roof of the orbita and frontal bone (Fig. 3A). MR imaging showed a lesion on the involved orbital roof with hypointense cystic lesions extending through the interhemispheric fissure (Fig. 3B, C). No enhancement was observed after administration of contrast
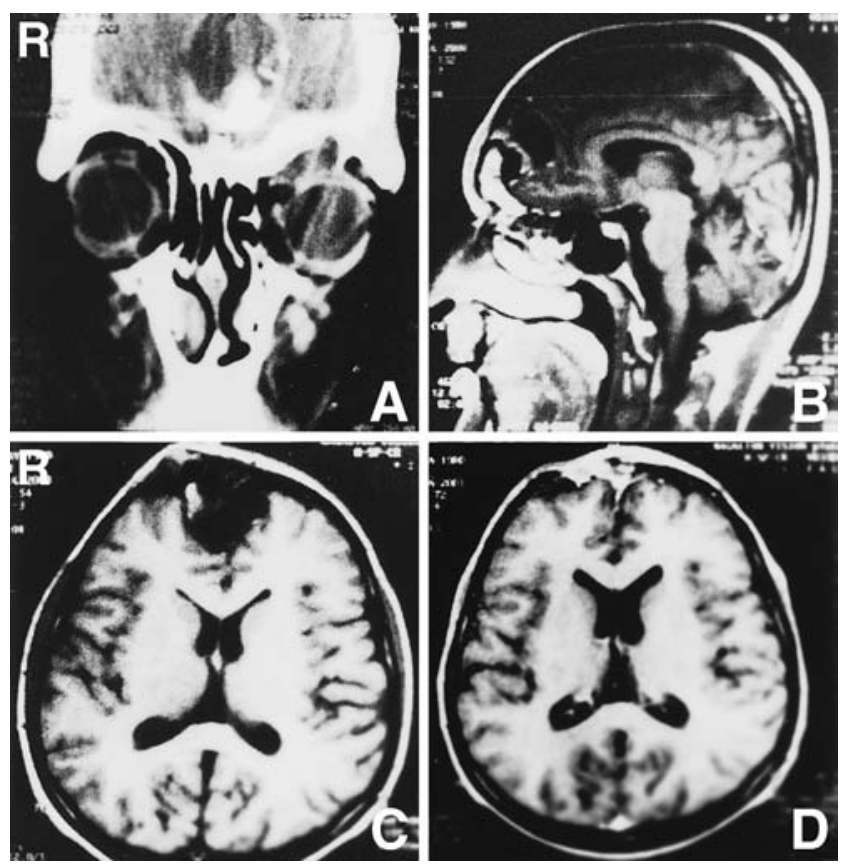

Fig. 3 Case 2. (A) Coronal CT scan. (B) Sagittal $T_{1}$-weighted magnetic resonance image. (C) Pre- and (D) postoperative $T_{1}$-weighted magnetic resonance images. Note the communication between the lesion and frontal sinus.

agent.

Right frontal craniotomy was performed. The cystic lesions with yellow mucinous material extending into the frontal lobe through dural defects were removed. The calcified mass lesion was totally removed and the dura was repaired with pericranium (Fig. 3D). The frontal sinus was curetted and packed with muscle. Histological examination showed that the wall of the cyst was mucocele, and the bony formation was osteoma (Fig. 4). The postoperative course was uneventful. Nine months later, a cranioplasty operation was performed to close the craniotomy defect.

\section{Discussion}

Osteomas and mucoceles both occur as isolated entities in the paranasal sinuses. In the case of the association of paranasal sinus osteoma and mucocele, the paranasal sinus osteoma has been considered to cause the mucocele by occlusion of the sinus openings. ${ }^{5,14)}$ The osteoma represents a mechanical obstruction that forces the mucocele to expand towards the cranial cavity. ${ }^{11}$ In the absence of osteoma, the mucocele would develop towards the orbit, frontal nasal fossae, or ethmoid. ${ }^{11}$ 
The cause of paranasal sinus osteomas is unknown, but developmental, traumatic, and infectious hypotheses have been proposed. ${ }^{17,18)}$ The osteomas in our patients were located around the junction of the embryonic cartilaginous ethmoid and membranous frontal bones. Such a location

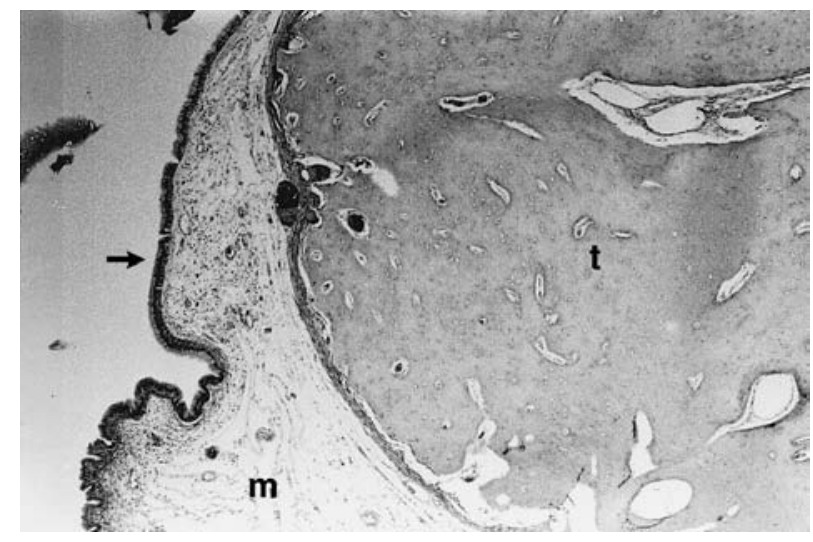

Fig. 4 Case 2. Photomicrograph showing apparently normal surface epithelium (arrow), edematous, myxoid stroma $(\mathrm{m})$, and apparently mature thick bone trabeculae $(t)$. HE stain, $\times 100$. indicates developmental causes. All reported lesions have been located at or around the frontoethmoidal junction (Table 1). ${ }^{1-8,11-14,16)}$

Absence of signs of sinus obstruction in a previous case suggested a small ectopic sinus not visualized by radiological methods or by direct observation during the surgery, or an intracranial connection of the paranasal sinus that disappeared early in the patient's life was the origin of the mucocele. ${ }^{13)}$ We were not able to find any kind of obstruction in the involved frontal sinuses in either of our cases. Absence of anatomical continuity between the mucocele and the frontal sinus other than that created by the osteoma indicated that the growing orbitoethmoidal osteoma had isolated the developing mucocele from the ethmoidal sinus. ${ }^{13)}$ We also found such findings in both our cases.

Isolated paranasal sinus osteomas are benign and slow-growing tumors, but are aggressive in the association with mucoceles. However, even partial removal of the lesions will prevent recurrence. ${ }^{1-8,11-14,16)}$ We suggest that although paranasal sinus osteoma is the primary pathology, the aggressiveness of the association may be due to the mucocele component. Calcification of the mucocele material may result in unexpected enlargement of the osteoma. This may also explain the absence of

Table 1 Summary of reported cases of intracranial mucoceles secondary to paranasal sinus osteomas

\begin{tabular}{|c|c|c|c|c|}
\hline Author (Year) & Age/Sex & Location & Symptoms and Signs & Compartment \\
\hline Cushing (1927) & $35 / \mathrm{M}$ & orbitoethmoid & $\begin{array}{l}\text { painful unilateral exophthalmos, } \\
\text { failing vision }\end{array}$ & intradural \\
\hline $\begin{array}{l}\text { Campbell and Gottschalk } \\
(1938)^{3)}\end{array}$ & $26 / \mathrm{M}$ & frontal & $\begin{array}{l}\text { headache, seizures, } \\
\text { noise "like water running" }\end{array}$ & intradural \\
\hline Pool et al. $(1962)^{14)}$ & 3 cases & $?$ & $?$ & ? \\
\hline Arseni et al. $(1973)^{1)}$ & $50 / ?$ & frontoethmoid & $\begin{array}{l}\text { headache, nausea, vomiting, fits, } \\
\text { hemiparesis, papilledema }\end{array}$ & intradural \\
\hline Diaz et al. $(1978)^{5)}$ & $15 / F$ & ethmoid & headache, anosmia & extradural \\
\hline Hesselink et al. $(1979)^{6)}$ & 2 cases & $?$ & $?$ & $?$ \\
\hline Lunardi et al. (1993) $)^{11)}$ & $\begin{array}{l}50 / \mathrm{M} \\
20 / \mathrm{F}\end{array}$ & $\begin{array}{l}\text { frontal } \\
\text { frontal }\end{array}$ & $\begin{array}{l}\text { frontal deformity, recurrent sinusitis } \\
\text { headache, papilledema, } \\
\text { reduction of visual acuity }\end{array}$ & $\begin{array}{l}\text { extradural } \\
\text { intradural }\end{array}$ \\
\hline Holness and Attia (1994) & $62 / \mathrm{M}$ & frontal & $\begin{array}{l}\text { headache, sloshing sound, } \\
\text { watery discharge, } \\
\text { personality change }\end{array}$ & intradural \\
\hline Shady et al. (1994) ${ }^{16)}$ & $17 / \mathrm{F}$ & frontal & $\begin{array}{l}\text { headache, fever, fatigue, vomiting, } \\
\text { diplopia, papilledema, abducens palsy }\end{array}$ & intradural \\
\hline Koga et al. (1995) ${ }^{8)}$ & $67 / F$ & frontoethmoid & dementia & ? \\
\hline Brunori et al. $(1995)^{2)}$ & $63 / \mathrm{M}$ & frontal & $\begin{array}{l}\text { headache, dementia, incontinence, } \\
\text { uncal herniation }\end{array}$ & intradural \\
\hline Manaka et al. (1998) ${ }^{12)}$ & $67 / \mathrm{M}$ & frontoethmoid & headache? & intradural \\
\hline Nakajima et al. $(2000)^{13)}$ & $46 / \mathrm{M}$ & ethmoid & seizure & intradural \\
\hline Present Case 1 & $20 / \mathrm{M}$ & frontal & headache, seizure & intradural \\
\hline Present Case 2 & $20 / \mathrm{M}$ & frontal & $\begin{array}{l}\text { headache, frontal deformity, } \\
\text { visual disturbance }\end{array}$ & intradural \\
\hline
\end{tabular}


continuity between the frontal sinus and the mucocele, and the aggressiveness of the association. Calcification of intracranial mucoceles is not rare $^{9,15)}$ and histological evaluation of the bone tissue in mucoceles has been controversial. ${ }^{10,15)}$ However, histological assessment of the lesions in our cases showed that the mucocele materials contained bone islands (Figs. 2 and 4).

The association of paranasal sinus osteoma and intracranially extending mucocele is rare and the osteoma is regarded as the primary pathology. However, unexpected enlargement of the osteoma may be due to calcification of the mucocele rather than growth of the osteoma. The presence of osteoma-like bone islands within the mucocele supports this hypothesis.

\section{References}

1) Arseni C, Chitescu M, Cioloca C: Intracerebral mucocele. Neurochirurgia (Stuttg) 16: 50-54, 1973

2) Brunori A, Bruni P, Delitala A, Greco R, Chiappetta F: Frontoethmoidal osteoma complicated by intracranial mucocele and hypertensive pneumocephalus: Case report. Neurosurgery 36: 1237-1238, 1995 (letter)

3) Campbell EH, Gottschalk RB: Osteoma of frontal sinus and penetration of lateral ventricle, with intermittent pneumocephalus. JAMA 3: 239-241, 1938

4) Cushing $\mathrm{H}$ : Experiences with orbito-ethmoidal osteomata having intracranial complications. Surg Gynecol Obstet 44: 721-742, 1927

5) Diaz F, Latchow R, Duvall AJ III, Quick CA, Erickson DL: Mucoceles with intracranial and extracranial extensions. Report of two cases. J Neurosurg 48: 284-288, 1978

6) Hesselink JR, Weber AL, New PFJ, Davis KR, Roberson GH, Taveras JM: Evaluation of mucoceles of the paranasal sinuses with computed tomography. Radiology 133: 397-400, 1979

7) Holness RO, Attia E: Osteoma of the frontoethmoidal sinus with secondary brain abscess and intracranial mucocele: Case report. Neurosurgery 35: 796-797, 1994 (letter)

8) Koga H, Moriyama $T$, Shirakawa K, Iwasaki K,
Matsuo T: [An intracranial mucocele secondary to an osteoma of the frontoethmoidal sinuses: a case report]. No Shinkei Geka Journal 4: 554-557, 1995 (Jpn, with Eng abstract)

9) Koike Y, Tokoro K, Chiba Y, Suzuki S, Murai M, Ito $\mathrm{H}$ : Intracranial extension of paranasal sinus mucocele: two case reports. Surg Neurol 45: 44-48, 1996

10) Lunardi P, Missori P, Di Lorenzo N: Intracerebral polyposis or osteoma? J Neurosurg 79: 801, 1993 (letter)

11) Lunardi P, Missori P, Di Lorenzo N, Fortuna A: Giant intracranial mucocele secondary to osteoma of the frontal sinuses: Report of two cases and review of the literature. Surg Neurol 39: 46-48, 1993

12) Manaka H, Tokoro K, Sakata K, Ono A, Yamamoto I: Intradural extension of mucocele complicating frontoethmoid sinus osteoma: Case report. Surg Neurol 50: 453-456, 1998

13) Nakajima $Y$, Yoshimine T, Ogawa $M$, Takanashi $M$, Nakamuta K, Maruno M, Hasegawa H, Yokota J: A giant intracranial mucocele associated with an orbitoethmoidal osteoma. Case report. J Neurosurg 92: 697-701, 2000

14) Pool JL, Potanos JN, Keueger EG: Osteomas and mucoceles of the frontal paranasal sinuses. $J$ Neurosurg 19: 130-135, 1962

15) Reddy PK, Rao GP, Prakasham A, Purnanand A, Sulochana C, Kumar RS, Reddy YR, Chandramala, Indumathi D: Intracerebral polyposis. Case report. J Neurosurg 78: 294-296, 1993

16) Shady JA, Bland LI, Kazee AM, Pilcher WH: Osteoma of the frontoethmoidal sinus with secondary brain abscess and intracranial mucocele: Case report. Neurosurgery 34: 920-923, 1994

17) Smith ME, Calcaterra TC: Frontal sinus osteoma. Ann Otol Rhinol Laryngol 98: 896-900, 1989

18) Wilkes SR, Trautmann JC, De Santo LW, Campbell RJ: Osteoma. An unusual cause of amaurosis fugax. Mayo Clin Proc 54: 258-260, 1979

Address reprint requests to: K. M. Akay, M.D., Mercimek Sokak 10/3, Etlik, Ankara 06010, Turkey. e-mail:kmakay45@hotmail.com 